\title{
Short communication: Associations between teat dimensions and milking-induced changes in teat dimensions and quarter milk somatic cell counts in dairy cows
}

\author{
I. Zwertvaegher,, S. De Vliegher,† B. Verbist, ${ }^{*}$ A. Van Nuffel, ${ }^{*}$ J. Baert, ${ }^{*}$ and S. Van Weyenberg ${ }^{* 1}$ \\ *The Institute for Agricultural and Fisheries Research (ILVO), Technology and Food Science Unit, Agricultural Engineering, \\ 9820 Merelbeke, Belgium \\ †M-team and Mastitis and Milk Quality Research Unit, Department of Reproduction, Obstetrics and Herd Health, Faculty of Veterinary Medicine, \\ Ghent University, 9820 Merelbeke, Belgium
}

\section{ABSTRACT}

Although many studies have examined the relation between a wide range of factors and quarter milk somatic cell count (qSCC), including physical characteristics of the teat and changes in teat tissue due to milking, the effect of short-term, milking-induced changes in teat dimensions on somatic cell count has not yet been investigated. To identify teat dimensions and milking-induced changes in teat dimensions associated with qSCC, we conducted a longitudinal study $\left(\mathrm{n}_{\text {herds }}=6, \mathrm{n}_{\text {cows }}=72, \mathrm{n}_{\text {measurements }}=12\right)$. Parity, stage of lactation, teat barrel diameter, and changes in teat barrel diameter during milking were identified as factors associated with qSCC. Teats with wider barrels had higher qSCC. Negative changes in the diameter of the teat barrel during milking (i.e., thinner teats postmilking compared with premilking) were associated with lower qSCC, whereas positive changes (i.e., thicker teats postmilking compared with premilking) were associated with higher qSCC. Selection toward more optimal teat characteristics may therefore result in improved milk quality and udder health. However, a threshold might exist for the maximum reduction in teat barrel diameter below which udder health is negatively influenced. If so, changes in teat barrel diameter might serve as an indicator for suboptimal milking and incorrect choice of teatcup liner or milking machine settings and thus help improve management of the herd.

Key words: dairy cow, teat dimension, quarter milk somatic cell count

\section{Short Communication}

Mastitis is one of the most common and costly diseases in dairy cattle (Halasa et al., 2007). During IMI,

\footnotetext{
Received April 18, 2012.

Accepted October 22, 2012

${ }^{1}$ Corresponding author: stephanie.vanweyenberg@ilvo.vlaanderen.
} be
SCC increases as part of the inflammatory response. In the absence of clinical symptoms, measurement of the SCC is the most frequently used indirect measure to detect subclinical mastitis (Beaudeau et al., 2002). Many studies have examined the relation between managerial, environmental, cow, and quarter factors, including the physical characteristics of the teat, and SCC. Teat length was not significantly associated with SCC (Seykora and McDaniel, 1986; Coban et al., 2009), whereas SCC generally increased with increasing teat diameter (Seykora and McDaniel, 1986; Chrystal et al., 1999). One study, however, reported the absence of an association between SCC and teat diameter in Gir cows (Porcionato et al., 2010). It is well known that machine milking induces changes in teat tissue (such as congestion and hyperkeratosis) and in teat dimensions. Although changes in teat tissue, such as teat thickness and teat end callosity, have been associated with udder health (Zecconi et al., 1996; Neijenhuis et al., 2001) and guidelines for acceptable changes in teat end thickness have been formulated (Hamann and Mein, 1996), no studies have actually examined the effect of changes in teat dimensions on udder health. The objectives of this study were to examine potential associations between teat dimensions and short-term, milking-induced changes in teat dimensions and quarter milk SCC.

A longitudinal study including 72 Holstein-Friesian cows from 6 Flemish dairy herds was conducted between June 2008 and May 2009. Over 1 yr, teat dimension and quarter milk somatic cell count (qSCC) measurements were performed monthly. Per herd, a cohort of 10 clinically healthy cows (assessed by visual inspection of the animal, udder, and milk) was randomly selected within parity blocks ( 4 heifers, 3 cows of second parity, and 3 cows of third or higher parity) at the beginning of the study. Before the end of the study, 18 out of 60 cohort cows were culled (ranging from 0 to 5 per herd) for a diversity of reasons, including problems with lameness, udder health, fertility, or milk production. All cohort cows culled before the 11th month of the study ( $\mathrm{n}=$ 
12) were replaced by randomly selected herd mates of the same parity. Based on the data of May 2009, the average herd size was 70 Holstein cows (ranging from 49 to 78 ), with an average production of $9,368 \mathrm{~kg}$ of milk per cow per year (ranging from 7,147 to 11,665 ). Cows were milked twice a day with round, narrow-bore liners on 2 farms and round, medium-bore liners on 4 farms. Automatic cluster removal was used on all farms. The herd vacuum level averaged $42.0 \mathrm{kPa}$ and ranged from 41.2 to 42.9 .

Quarter milk samples were collected and SCC was determined by means of a Fossomatic 5000 FC (Foss, Eden Prairie, MN). A natural logarithmic transformation of qSCC (LnqSCC) was performed to obtain a normal distribution.

Within $15 \mathrm{~d}$ before and $15 \mathrm{~d}$ after qSCC recordings, teat dimensions (length and diameters) were determined using a 2-dimensional vision-based measuring technique (Zwertvaegher et al., 2011) immediately before and after evening milking. All pictures were analyzed using a software program to determine teat length and teat diameters at 3 different heights of the teat; that is, at $75 \%$ (further referred to as the teat base), $50 \%$ (teat barrel), and $25 \%$ (teat apex) relative to the teat end. Absolute and relative changes in teat length and teat diameters due to milking were calculated. This resulted in 16 different teat dimensions available for further study: teat length, teat diameter at teat base, teat barrel, and teat apex, respectively, as measured pre- and postmilking, as the absolute changes [postmilking value - premilking value], and as percentage changes relative to the premilking value [(postmilking value - premilking value)/premilking value $\times 100]$.

A 4-level (herd, cow, quarter, and observation) model was fit with LnqSCC as the dependent variable using SAS 9.3 (SAS Institute Inc., Cary, NC). Herd, cow, and quarter were included as random effects to correct for clustering of cows within herds, quarters within cows, and repeated measurements within quarters, respectively. Measurement was forced into all models as fixed effect to model the repeated measurements. The covariance between repeated measurements was modeled using the auto-regressive (1) structure.

The regression-model building process involved several steps as described previously (De Vliegher et al., 2004). In addition to the 16 different teat dimensions, the effects of parity $(1,2,2+)$, stage of lactation (0-30, 31-60, 61-120, 121-180, 181-240, 240+ DIM), and quarter position (front, hind) on LnqSCC were assessed. First, univariable associations were tested between all independent variables (16 teat dimensions, parity, stage of lactation, and quarter position) and LnqSCC. Statistical significance in this step was assessed at $P<0.15$. Second, Pearson correlation and
Spearman correlation coefficients were calculated among the significant independent variables to avoid multicollinearity. If 2 variables had a correlation coefficient $\geq 0.6$, only one was selected for further analysis. In a third step, multivariable models were fit using a backward stepwise procedure at $P<0.05$. Finally, the relevant 2-, 3-, and 4-way interactions were tested between the fixed effects included in the final model, and removed in a backward stepwise manner when nonsignificant $(P>0.05)$. Least squares means (LSM) were calculated for the independent variables in the final model. The fit of the final model was evaluated by examination of the normal probability plots of residuals and by inspection of the residuals plotted against the predicted values.

Descriptive statistics (mean, standard deviation, and range) for the 16 different teat dimensions are presented in Table 1. The increase in teat length due to milking averaged $9.2 \%$ but both shorter and longer teats postmilking occurred (up to $25.6 \%$ decrease and $64.4 \%$ increase). The average relative changes in diameters were close to zero but changes postmilking compared with premilking varied widely (e.g., -24.8 to $45.4 \%$ for diameter at the teat base). In Table 2, the geometric mean qSCC per quartile of the different teat dimensions are shown. The largest proportion of variation in LnqSCC, as studied using a 4-level null model (no fixed effects included), resided at the observation level (62.2\%), followed by the quarter (20.3\%), cow $(13.5 \%)$, and herd levels $(4.1 \%)$, respectively. Including the significant fixed effects in the model explained $20 \%$ of the total variance of LnqSCC.

Similar to results of other studies (Reneau, 1986; Bartlett et al., 1990), LnqSCC increased significantly with parity and followed a nonlinear curve over lactation stage (Table 3). Moreover, LnqSCC significantly increased with increasing diameter of the teat barrel (Table 3), corresponding with previous findings (Higgins et al., 1980; Seykora and McDaniel, 1986; Chrystal et al., 1999). Quarters with larger teat diameters tended to have more clinical and subclinical mastitis (Hickman, 1964), and larger than herd-average teat diameter was identified as risk factor for mastitis by Slettbakk et al. (1995). Larger diameter teats tend to have larger teat orifices and wider teat canals (Rathore and Sheldrake, 1977; Chrystal et al., 1999), which may explain the association between teat diameter, SCC, and mastitis. Some authors, however, found no relationship between teat diameter and SCC (Porcionato et al., 2010), IMI (Bakken, 1981), or mastitis prevalence (Binde and Bakke, 1984). Different methods of measuring teat dimension, different definitions of mastitis and IMI, differences between statistical analyses, and breed may explain the contradictory results. 
Table 1. Descriptive statistics (mean, SD, and range) of teat length and diameter of the teat base, teat barrel, and teat apex as measured pre- and postmilking, as absolute and relative changes

\begin{tabular}{|c|c|c|}
\hline Teat dimension & Mean $\pm \mathrm{SD}$ & Range \\
\hline \multicolumn{3}{|l|}{ Premilking (mm) } \\
\hline Teat length & $54.3 \pm 9.2$ & $28.5-83.1$ \\
\hline Diameter at teat base ${ }^{1}$ & $29.7 \pm 3.8$ & $21.2-52.0$ \\
\hline${\text { Diameter at teat } \text { barrel }^{2}}^{2}$ & $27.8 \pm 3.3$ & $19.1-48.9$ \\
\hline Diameter at teat apex ${ }^{3}$ & $23.7 \pm 2.5$ & $16.4-37.5$ \\
\hline \multicolumn{3}{|l|}{ Postmilking (mm) } \\
\hline Teat length & $59.1 \pm 10.7$ & $27.8-93.5$ \\
\hline Diameter at teat base & $29.8 \pm 3.2$ & $21.7-48.6$ \\
\hline Diameter at teat barrel & $27.0 \pm 2.6$ & $20.7-45.7$ \\
\hline Diameter at teat apex & $23.7 \pm 2.1$ & $16.9-37.1$ \\
\hline \multicolumn{3}{|l|}{ Absolute change $^{4}(\mathrm{~mm})$} \\
\hline Teat length & $4.8 \pm 6.2$ & $-15.2-31.6$ \\
\hline Diameter at teat base & $0.0 \pm 2.8$ & $-10.3-12.2$ \\
\hline Diameter at teat barrel & $-0.8 \pm 1.9$ & $-9.2-5.5$ \\
\hline Diameter at teat apex & $0.0 \pm 1.5$ & $-6.3-4.7$ \\
\hline \multicolumn{3}{|l|}{ Relative change $^{5}(\%)$} \\
\hline Teat length & $9.2 \pm 11.7$ & $-25.6-64.4$ \\
\hline Diameter at teat base & $0.7 \pm 9.2$ & $-24.8-45.4$ \\
\hline Diameter at teat barrel & $-2.4 \pm 6.5$ & $-22.9-25.0$ \\
\hline Diameter at teat apex & $0.3 \pm 6.1$ & $-18.6-23.1$ \\
\hline
\end{tabular}

${ }^{1}$ Diameter measured at $75 \%$ of the teat relative to the teat end.

${ }^{2}$ Diameter measured at $50 \%$ of the teat relative to the teat end.

${ }^{3}$ Diameter measured at $25 \%$ of the teat relative to the teat end.

${ }^{4}$ Postmilking value - premilking value.

${ }^{5}$ Calculated as (postmilking value - premilking value)/premilking value $\times 100$.

Negative changes in teat barrel diameter (i.e., thinner teats postmilking compared with premilking) were associated with lower LnqSCC, whereas positive changes (i.e., thicker teats postmilking compared with premilking) were significantly associated with higher LnqSCC (Figure 1). The described changes are milking-induced

Table 2. Crude geometric mean quarter milk SCC $(\times 1,000$ cells $/ \mathrm{mL})$ for the different teat dimension variables per quartile

\begin{tabular}{|c|c|c|c|c|}
\hline \multirow[b]{2}{*}{ Teat dimension } & \multicolumn{4}{|c|}{ Quartile } \\
\hline & 1 & 2 & 3 & 4 \\
\hline \multicolumn{5}{|l|}{ Premilking } \\
\hline Teat length & 34.89 & 47.39 & 48.67 & 56.24 \\
\hline Diameter at teat base ${ }^{1}$ & 48.77 & 40.73 & 46.04 & 49.49 \\
\hline Diameter at teat barrel $^{2}$ & 51.85 & 37.04 & 45.49 & 51.80 \\
\hline Diameter at teat apex ${ }^{3}$ & 43.42 & 40.16 & 46.13 & 56.26 \\
\hline \multicolumn{5}{|l|}{ Postmilking } \\
\hline Teat length & 34.57 & 44.55 & 48.74 & 60.31 \\
\hline Diameter at teat base & 43.41 & 40.55 & 46.66 & 55.09 \\
\hline Diameter at teat barrel & 41.27 & 38.07 & 43.76 & 65.84 \\
\hline Diameter at teat apex & 43.32 & 38.69 & 46.15 & 58.52 \\
\hline \multicolumn{5}{|l|}{ Absolute change $^{4}$} \\
\hline Teat length & 43.16 & 42.98 & 46.50 & 52.46 \\
\hline Diameter at teat base & 39.00 & 46.45 & 51.36 & 48.65 \\
\hline Diameter at teat barrel & 37.34 & 42.93 & 48.26 & 58.50 \\
\hline Diameter at teat apex & 42.40 & 48.41 & 48.07 & 45.88 \\
\hline \multicolumn{5}{|l|}{ Relative change ${ }^{5}$} \\
\hline Teat length & 43.00 & 46.15 & 46.28 & 49.28 \\
\hline Diameter at teat base & 39.22 & 46.37 & 51.61 & 48.22 \\
\hline Diameter at teat barrel & 36.65 & 43.63 & 47.24 & 59.92 \\
\hline Diameter at teat apex & 41.55 & 49.51 & 48.53 & 45.34 \\
\hline
\end{tabular}

${ }^{1}$ Diameter measured at $75 \%$ of the teat relative to the teat end.

${ }^{2}$ Diameter measured at $50 \%$ of the teat relative to the teat end.

${ }^{3}$ Diameter measured at $25 \%$ of the teat relative to the teat end.

${ }^{4}$ Postmilking value - premilking value.

${ }^{5}$ Calculated as (postmilking value - premilking value)/premilking value $\times 100$. 
Table 3. Final multilevel (herd, cow, quarter, observation) linear model describing teat dimensions associated with the natural logarithmic transformation of the quarter SCC (LnqSCC)

\begin{tabular}{|c|c|c|c|c|c|}
\hline \multirow[b]{2}{*}{ Independent variable and level } & \multirow[b]{2}{*}{$\mathrm{N}_{\text {observations }}$} & \multicolumn{4}{|c|}{ LnqSCC } \\
\hline & & $\beta^{1}$ & $\mathrm{SE}$ & $P$-value & LSM \\
\hline Constant & & 3.7 & 0.5 & - & \\
\hline Measurement & & & & 0.06 & \\
\hline 1 & 159 & Ref. $^{2}$ & - & & 3.5 \\
\hline 2 & 138 & 0.0 & 0.1 & & 3.5 \\
\hline 3 & 165 & 0.0 & 0.1 & & 3.5 \\
\hline 4 & 150 & 0.0 & 0.1 & & 3.6 \\
\hline 5 & 145 & 0.3 & 0.1 & & 3.8 \\
\hline 6 & 144 & 0.2 & 0.1 & & 3.7 \\
\hline 7 & 164 & 0.1 & 0.1 & & 3.7 \\
\hline 8 & 182 & 0.0 & 0.1 & & 3.5 \\
\hline 9 & 192 & 0.0 & 0.1 & & 3.6 \\
\hline 10 & 159 & -0.2 & 0.1 & & 3.3 \\
\hline 11 & 198 & 0.0 & 0.1 & & 3.5 \\
\hline 12 & 143 & 0.0 & 0.1 & & 3.5 \\
\hline Parity & & & & 0.002 & \\
\hline 1 & 310 & Ref. & - & & 3.2 \\
\hline 2 & 712 & 0.4 & 0.1 & & 3.6 \\
\hline $2+$ & 917 & 0.6 & 0.2 & & 3.9 \\
\hline Lactation stage (DIM) & & & & $<0.001$ & \\
\hline $0-30$ & 147 & Ref. & - & & 3.2 \\
\hline $31-60$ & 159 & -0.3 & 0.1 & & 2.9 \\
\hline $61-120$ & 369 & 0.0 & 0.1 & & 3.2 \\
\hline $121-180$ & 368 & 0.5 & 0.1 & & 3.7 \\
\hline $181-240$ & 318 & 0.9 & 0.1 & & 4.1 \\
\hline $240+$ & 578 & 1.3 & 0.1 & & 4.5 \\
\hline Premilking diameter of teat barrel $^{3}$ & 1,939 & 0.05 & 0.0 & 0.007 & \\
\hline Percentage change in diameter of teat barrel ${ }^{4}$ & 1,939 & 0.02 & 0.0 & $<0.001$ & \\
\hline
\end{tabular}

changes of cistern diameter or teat wall thickness or a combination of both. Reduced intramammary pressure and muscle tone (Hamann et al., 1993) and elongation of the teat (Isaksson and Lind, 1992) may account for a decrease in teat diameter after milking, whereas accumulation of fluid in the teat wall results in positive changes in teat wall thickness (Hamann and Mein, 1990; Hamann et al., 1993). Congestion or edema may impair blood circulation and thus reduce the efficiency of teat defense mechanisms such as neutrophil activity (Hamann and Osteras, 1994), which may explain the increased SCC with increasing positive diameter changes at the teat barrel found in this study. On the other hand, large decreases in teat diameter due to milking might affect udder health because excessively high cyclic pressures applied to the teat by the liner could remove fluid from the blood vessels and thus restrict the blood supply to the tissues. Therefore, despite the significant decrease in LnqSCC with decreasing diameter change at the barrel reported in this study, we hypothesize that a threshold exists for the maximum reduction in diameter after milking at this region of the teat, below which udder health is negatively influenced. Once this range is determined, the changes in teat dimensions could serve as indicators for suboptimal milking and improper choice of teatcup liner or milking machine settings. Such a range has already been described for teat end thickness. Hamann and Mein (1996) suggested the use of a threshold of $5 \%$ increase and $5 \%$ decrease in teat end thickness postmilking compared with premilking to evaluate the effectiveness of pulsation (in relation to vacuum level and liner type). In our study, however, no relation of relative changes in diameter of the teat apex and qSCC was found. This may be because diameters were not determined low enough on the teat, or no classification (comparable to the threshold of $\pm 5 \%$ ) was made in teat end diameter changes.

Although no significant relationships were found between LnqSCC and teat length, which is in agreement with other studies (Seykora and McDaniel, 1986; Coban et al., 2009), or for premilking diameters of the apex and the base of the teat, it is known that the ratio of teat dimensions (length and diameters) with liner characteristics is important for good teat condition and milking characteristics (Mein et al., 1983; Rasmussen et al., 2004). In this respect, knowledge on how the 


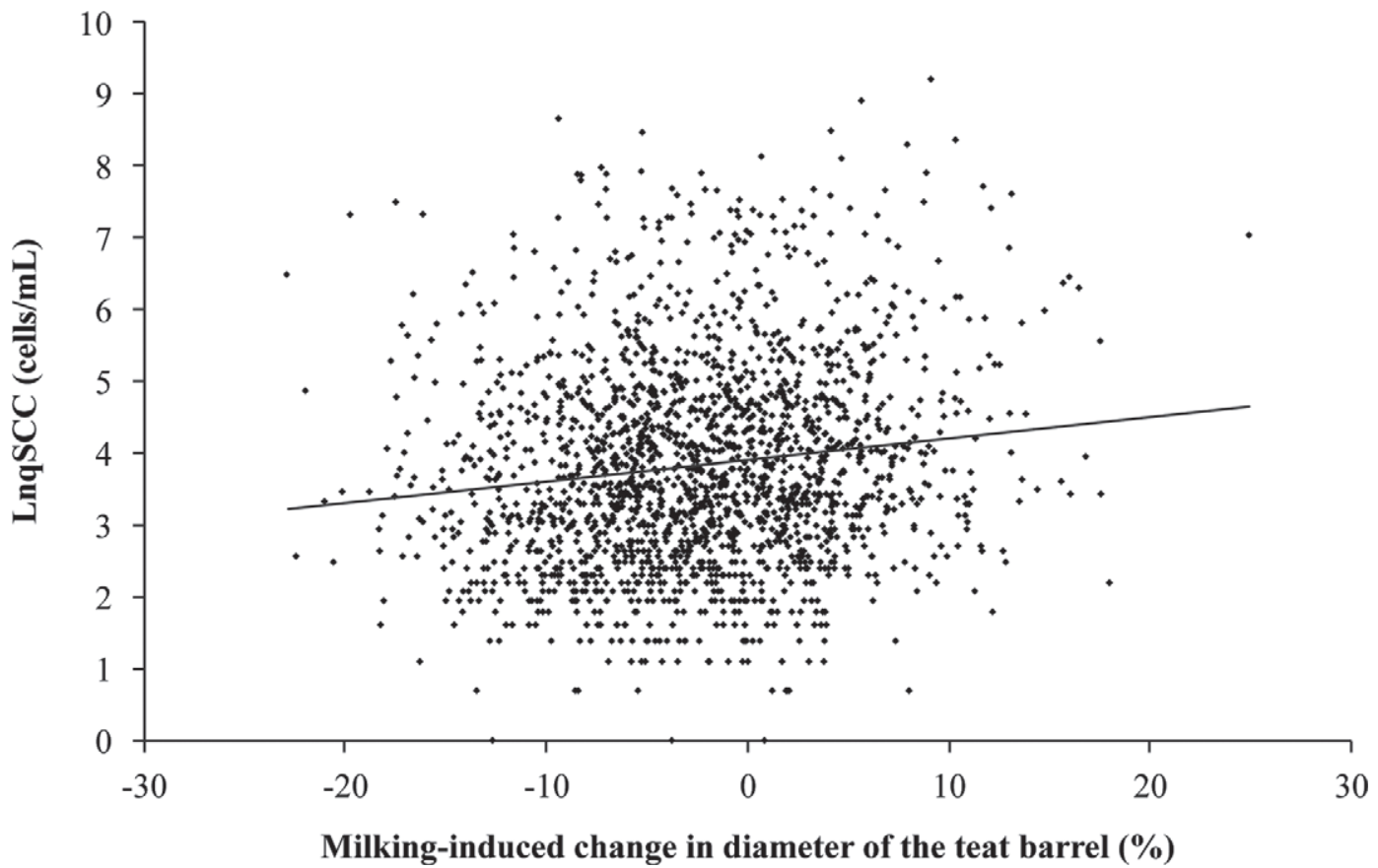

Figure 1. Scatterplot for the natural logarithmic transformation of the quarter SCC (LnqSCC) plotted against the percentage change in the teat barrel diameter postmilking compared with premilking (not corrected for clustering or other factors).

teatcup liner should relate to the teat under certain milking machine settings (i.e., pulsation and vacuum) is required for better liner selection.

As the diameter of the teat barrel and the relative changes in this diameter are associated with SCC, selection of specific teat characteristics might result in improved milk quality and udder health. Knowledge of the level (herd, cow, quarter, observation) at which most variation in these teat dimension factors resides and identification of factors explaining (part of) this variation are prerequisites for more directed selection. A risk factor analyses including herd, cow, and quarter factors, as well as milking machine settings and milking characteristics, should be conducted, and could include culture results rather than SCC values.

In conclusion, both premilking values and relative changes of the teat barrel diameter were significantly associated with qSCC, indicating that these teat dimensions could be useful to improve milk quality and udder health, either by directed (genetic) selection toward more optimal teat characteristics or as indicators of improper milking and incorrect machine settings, including choice of teatcup liner.

\section{ACKNOWLEDGMENTS}

This research was funded by the Institute for the Promotion of Innovation through Science and Technology in Flanders (IWT-Vlaanderen, grant no. 50670), the
Institute for Agricultural and Fisheries Research $(\mathrm{PhD}$ scholarship, ILVO, Merelbeke, Belgium), and Ghent University (UGent, Belgium). The authors thank Annelies Genbrugge and the technical staff of ILVO for the field work support.

\section{REFERENCES}

Bakken, G. 1981. Relationships between udder and teat morphology, mastitis and milk production in Norwegian Red cattle. Acta Agric. Scand. 31:438-444.

Bartlett, P. C., G. Y. Miller, C. R. Anderson, and J. H. Kirk. 1990. Milk production and somatic cell count in Michigan dairy herds. J. Dairy Sci. 73:2794-2800.

Beaudeau, F., C. Fourichon, H. Seegers, and N. Bareille. 2002. Risk of clinical mastitis in dairy herds with a high proportion of low individual milk somatic-cell counts. Prev. Vet. Med. 53:43-54.

Binde, M., and H. Bakke. 1984. Relationships between teat characteristics and udder health - A field survey. Nord. Vet. Med. $36: 111-116$

Chrystal, M. A., A. J. Seykora, and L. B. Hansen. 1999. Heritabilities of teat end shape and teat diameter and their relationships with somatic cell score. J. Dairy Sci. 82:2017-2022.

Coban, O., N. Sabuncuoglu, and N. Tuzemen. 2009. A study on relationships between somatic cell count (SCC) and some udder traits in dairy cows. J. Anim. Vet. Adv. 8:134-138.

De Vliegher, S., H. Laevens, H. W. Barkema, I. R. Dohoo, H. Stryhn, G. Opsomer, and A. de Kruif. 2004. Management practices and heifer characteristics associated with early lactation somatic cell count of Belgian dairy heifers. J. Dairy Sci. 87:937-947.

Halasa, T., K. Huijps, O. Osteras, and H. Hogeveen. 2007. Economic effects of bovine mastitis and mastitis management: A review. Vet. Q. 29:18-31.

Hamann, J., and G. A. Mein. 1990. Measurement of machine-induced changes in thickness of the bovine teat. J. Dairy Res. 57:495-505.

Hamann, J., and G. A. Mein. 1996. Teat thickness changes may provide biological test for effective pulsation. J. Dairy Res. 63:179-189. 
Hamann, J., G. A. Mein, and S. Wetzel. 1993. Teat tissue reactions to milking: Effects of vacuum level. J. Dairy Sci. 76:1040-1046.

Hamann, J., and O. Osteras. 1994. Teat tissue reactions to machine milking and new infection risk. II. Special aspects. Bull. Int. Dairy Fed. 297:35-41.

Hickman, C. G. 1964. Teat shape and size in relation to production characteristics and mastitis in dairy cattle. J. Dairy Sci. 47:777782 .

Higgins, S., R. K. Moore, and B. W. Kennedy. 1980. Heritabilities of teat conformation traits and their relationships with somatic cell counts in Holsteins. Can. J. Anim. Sci. 60:231-239.

Isaksson, A., and O. Lind. 1992. Teat reactions in cows associated with machine milking. Zbl. Vet. Med. A 39:282-288.

Mein, G. A., M. R. Brown, and D. M. Williams. 1983. Pulsation failure as a consequence of milking with short teatcup liners. J. Dairy Res. 50:249-258.

Neijenhuis, F., H. W. Barkema, H. Hogeveen, and J. P. T. M. Noordhuizen. 2001. Relationship between teat-end callosity and occurrence of clinical mastitis. J. Dairy Sci. 84:2664-2672.

Porcionato, M. A. D., W. V. B. Soares, C. B. M. dos Reis, C. S. Cortinhas, L. Mestieri, and M. V. dos Santos. 2010. Milk flow, teat morphology and subclinical mastitis prevalence in Gir cows. Pesquisa Agropecu. Bras. 45:1507-1512.
Rasmussen, M. D., J. Baines, F. Neijenhuis, and E. Hillerton. 2004. Teat condition and mastitis. Pages 43-48 in Proc. IDF World Dairy Summit 2003: 100 Years with Liners and Pulsators in Machine Milking. Int. Dairy Fed./Fed. Int. Laiterie, Brussels, Belgium.

Rathore, A. K., and R. F. Sheldrake. 1977. Teat orifice stretchability associated with teat diameter gradient and milk yield in lactating cows. Anim. Prod. 24:215-220.

Reneau, J. K. 1986. Effective use of dairy herd improvement somatic cell counts in mastitis control. J. Dairy Sci. 69:1708-1720.

Seykora, A. J., and B. T. McDaniel. 1986. Genetics statistics and relationships of teat and udder traits, somatic cell counts, and milk production. J. Dairy Sci. 69:2395-2407.

Slettbakk, T., A. Jorstad, T. B. Farver, and J. C. Holmes. 1995. Impact of milking characteristics and morphology of udder and teats on clinical mastitis in first-lactation and second-lactation Norwegian cattle. Prev. Vet. Med. 24:235-244.

Zecconi, A., V. Bronzo, R. Piccinini, P. Moroni, and G. Ruffo. 1996. Field study on the relationship between teat thickness changes and intramammary infections. J. Dairy Res. 63:361-368.

Zwertvaegher, I., J. Baert, J. Vangeyte, A. Genbrugge, and S. Van Weyenberg. 2011. Objective measuring technique for teat dimensions of dairy cows. Biosystems Eng. 110:206-212. http://dx.doi org/10.1016/j.biosystemseng.2011.09.009. 